\title{
A Missionary Journey to the Sac-Fox Indians, 1834
}

\author{
By Roger L. Nichols
}

In a recent history of the Sac and Fox Indians its author concluded that, at least during most of the nineteenth century, these tribes were thorough going pagans. $\mathrm{He}$ assumed this rejection of the white man's religion was not because the Indians refused to change their religious ideas, but because of "a lack of Christian missionary zeal among the whites."

On the other hand, this account demonstrates the Indians' opposition to Christianity, and portrays the obstacles encountered by missionaries attempting to carry their religion to these natives.

The Black Hawk War forced a final migration of the SacFox remnant into what is now Iowa. The Indians' defeat also produced wide-spread publicity which in turn kindled an added interest in them by several groups. One of these, the Stockbridge Indians, who lived on the Fox River at Statesburg (Kaukauna, Wisconsin), claimed "the Sac and Fox and Delaware tribes of Indians are our friends and relatives." The Stockbridges were semi-Christian and fairly literate compared to most tribes in the Old Northwest. Missionaries had first reached them in 1734, and ministers and teachers served their tribe continuously after that time. Originally transplanted from western New York state in the 1820's, the Stockbridges were excited and pleased when Black Hawk visited their village on his return trip from Washington, D.C. to Iowa in the summer of 1833. The famous warrior's presence aroused their curiosity, and tribal leaders decided to pay their noted guest a return visit the following year.

While preparing for their jaunt to Iowa, several tribal leaders contacted the American Board of Commissioners for Foreign Missions. This group supported their mission, placing the tribe under the tutelage of the Reverend Cutting Marsh in 1830. In their request, the Indians asked "if there is not some way that we can make our visit subserve ... the 




SAC-Fox LANDS

The Sac and Fox Indians united in the middle 1770's and moved to this Mississippi land. They developed a complex social organization and were noted for their conservatism in adopting white customs. 
great object of your society. Can we not tell them (the Sacs and Foxes) of the great benefits we have received from being taught the gospel?" They also begged the American Board to send a missionary along to Iowa. Later that same year, Reverend Marsh, their missionary, wrote his superiors asking permission to accompany the tribal delegation the following spring.

These requests, one from the Stockbridges and the other from their missionary, fit smoothly into the American Board's plans. The United States government Indian removal policy forced them to close many Indians missions and schools, and they were anxious to explore new opportunities among the trans-Mississippi tribes. In addition to already established missions among the Cherokees, Choctaws, Ojibwas, and Stockbridges, the Board hoped to initiate missions among the Sioux, Sacs, and Foxes.

To facilitate these plans, they decided Marsh should accompany the Stockbridges to Iowa. This delighted the young missionary, and he wrote, "Felt indeed to bless God for the] opportunity wh[ich] will thereby be afforded me of doing good and of extending to those benighted pagans the kn[owledge] of salvation."

At the same time, the American Board enlisted Lewis Cass, Secretary of War, as an influential ally. He issued circulars asking army officers and Indian agents to cooperate with the missionaries so that "every facility may be extended for the accomplishment of their purposes."

In spite of the avowed religious aims, the delegation received some criticism from the Green Bay Intelligencer. Its editor claimed the Stockbridges were more interested in buying land west of the Mississippi, than in bringing Christianity to the Sacs and Foxes. The Indians hotly denied this charge, but the editor had the last word.

At the same time the American Board notified three of its other missionaries, the Reverends Cyrus Kingsbury and Cyrus Byington, and Dr. Thomas Williamson, of their parts in the plan. They were to meet Marsh at Rock Island, offer their suggestions, give him any information they had, and Dr. Williamson was to accompany him. The others would then return 
to St. Louis and from there travel up the Missouri to visit several tribes of the plains.

Finally the preparations were complete, and the missionary conducted a religious service in which he bade the tribe farewell, reminding them of their obligations and duties during his absence. Marsh felt some qualms about leaving and wrote "I felt a momentary sorrow in leaving, but duty . . . calls and therefore I desire to go cheerfully."

After the service, Marsh and five tribal leaders boarded their bark canoe and headed up the Fox River. The Stockbridges were not skilled campers, and one night a violent thunder storm blew down their tents drenching everyone. A few days later they reached Fort Winnebago at the Fox-Wisconsin portage, where they rested briefly. Then they continued down the Wisconsin River to Prairie du Chien, arrivng on June 25, 1834. Here Marsh hoped to meet Dr. Williamson on his return from Fort Snelling, but the doctor had already left for Rock Island. The missionary also tried to visit the Indian Agent, General Joseph M. Street, but he, too, was gone. Then Marsh and his Indian companions boarded a river steamer headed for Rock Island.

On June 28 the boat reached its destination, but Marsh again missed the elusive doctor. Rather than continue searching for Williamson, he called on Marmaduke S. Davenport, the U. S. Indian Agent for the Sacs and Foxes. Marsh found the agent "quite an agreeable man-somewhat reserved in his manner, yet intelligent." Davenport received him hospitably and seemed interested, but told the missionary his success would depend on the feelings and cooperation of George Davenport, a local fur trader, and Antoine Le Claire, the U. S. interpreter, as both these men had a great influence over the Indians. During his earlier meeting with the chiefs, agent Davenport, mentioned Dr. Williamson's proposal for establishing schools and missions among their people, but reported they were not interested. News that the Indians not only were disinterested, but actually opposed these suggestions startled Marsh. He apparently thought they would be overjoyed at receiving churches and schools from the white men. After recovering from the initial shock, he wrote "was not cast down, for God will uphold and bless his own cause." 


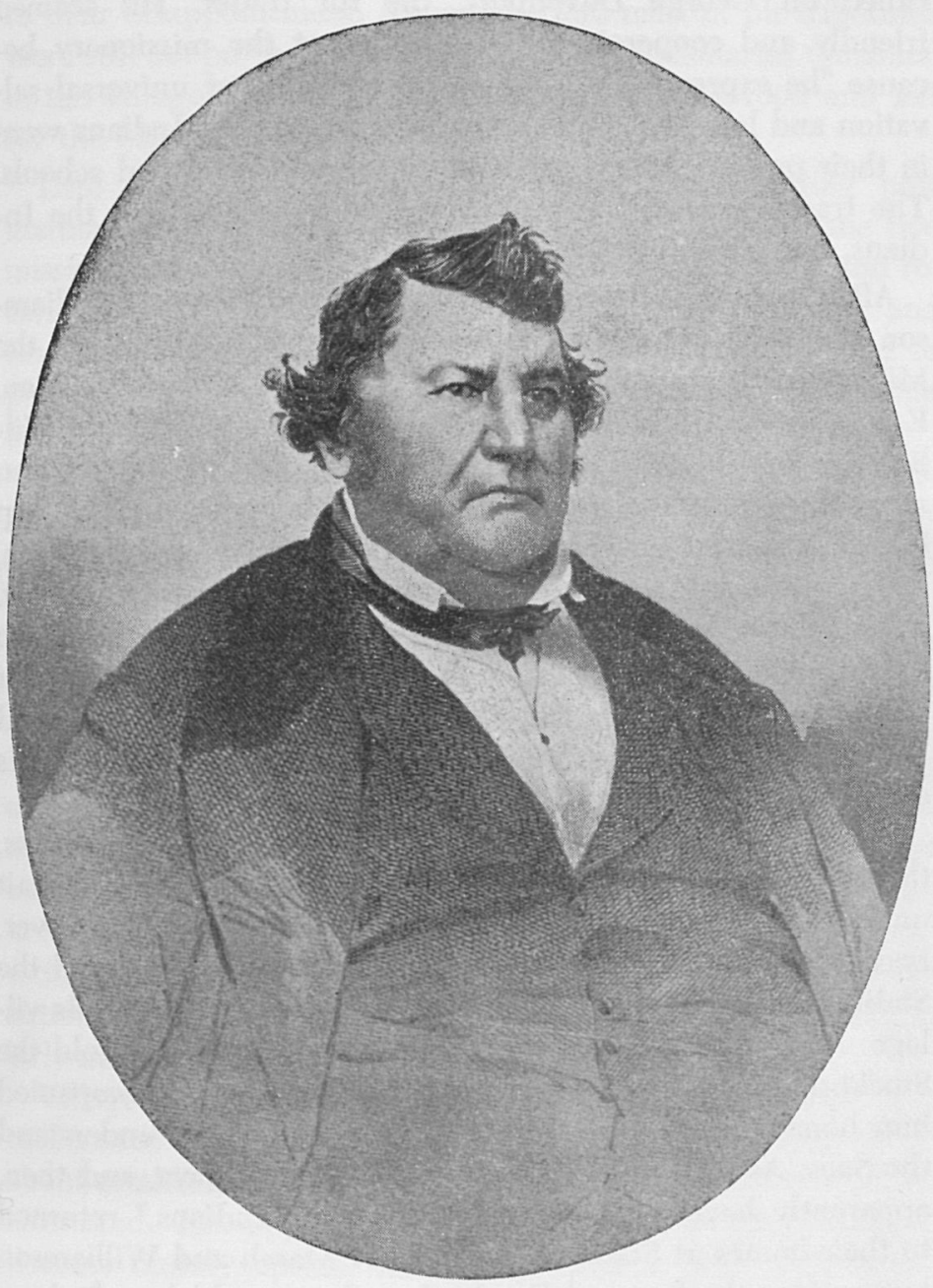

Antorne LeClaire

Famous Iowa Indian interpreter and one of the founders of Davenport. Author of a biography on Black Hawk and married to the granddaughter of a Sac chief. He died September 25, 1861. 
Finding the Indian agent little actual help, Marsh next called on George Davenport, the fur trader. He seemed friendly and cooperative, but soon upset the missionary because "he expressed a belief in the doctrine of universal salvation and labored ... to show how happy the Indians were in their present state," without any missionaries and schools. The trader agreed that a mission would be good for the Indians, but refused to help.

After this unsuccessful visit, Marsh heard that Dr. Williamson was at Yellow Banks, a settlement on the east side of the Mississippi, a short distance south of the Iowa River junction. Early Monday, July 1, he boarded a steamboat and met Williamson for the first time the following day. The two men spent their time and energy pouring over plans for their trip inland. The next day the Reverends Kingsbury and Byington, both experienced Indian missionaries, arrived from St. Louis. They recommended that Williamson accompany Marsh to Appenoose's village, on the south side of the Des Moines River about 125 miles from the Mississippi. They also suggested Williamson take charge of any new mission established in this area.

When their missionary left Rock Island for Yellow Banks, the Stockbridge delegation remained behind, planning to wait until the Sacs returned from their summer hunt. However, because of hot weather and a fear of sickness, they asked the Stabber (Pashepaho), a Sac chief, permission to visit his village. At first he objected, but finally consented when told the Stockbridges had their own food supply. They accompanied him home, but without an interpreter could not understand the Sacs. As a result they remained only five days, and then, apparently having their fill of "living like Indians," returned to their homes at Statesburg. This left Marsh and Williamson to convince the Sac and Fox leaders they would benefit from schools and missions.

Their business in Yellow Banks completed, the two missionaries hired horses and an interpreter, and set out for Appenoose's village, arriving there July 10 . This settlement was new, having been built that same year. It consisted of eight lodges, and about 250 people lived there. This was one of the larger Sac villages, and the missionaries fervently hoped they 
could get the chief's consent for a mission or a school. Much to their disappointment, Appenoose and most of his tribesmen were still out on their summer hunt. The missionaries remained in the village for several days, but ran short of food and left for the Mississippi on July 14.

Late the next afternoon they reached the trading post maintained by William Phelps and his brother. Here the two missionaries separated. Williamson continued eastward and returned to Cincinnati, Ohio, to finish theological school, and Marsh remained, "feeling somewhat unwell." Indian food or perhaps a change in water brought on a severe attack of what Marsh called dysentery.

During his enforced visit with the Phelps brothers, the missionary carefully observed his surroundings. Practically everyone stopping at the post had some habit or trait he disapproved of. Almost constant drinking, fighting, gambling, swearing, and Sabbath breaking appalled him. In spite of his feeling that the Phelps brothers were "professed infidels," they treated Marsh hospitably.

On July 21 he felt sufficiently recovered and joined a group of traders on a canoe trip up the Des Moines. They reached Appenoose's village on July 30 , and the Indians, with their customary hospitality, invited them to attend a series of feasts held each evening. Marsh spent his days observing the interesting aspects of Sac-Fox culture, and trying to interest the natives in Christianity and education. His efforts were singularly unsuccessful.

Village life was pleasant, but Marsh anxiously worked for a conference with the chief. The two men talked informally about establishing a mission or school, and the Indian seemed interested. His apparent cooperation led the missionary to become unduly optimistic. Finally, after a week Appenoose agreed to confer with him the next morning, August 7. However, that afternoon one of the traders brought several kegs of whiskey, and in a short time all was bedlam. The chief, as well as most of the tribe, became drunk, and Marsh lost this opportunity. He retired early, complaining bitterly about the Indians' lack of dependability. His feeling toward the whites who brought whiskey was more one of disgust or pity, and he wrote, "How awful . . . must the day of judgment be to 
such as for a little paltry gain can be accessory to so much evil and wretchedness...."

The next morning Marsh and Appenoose discussed the missionary's plan for a mission at the village. The chief, suffering from the effects of his drunken spree, could hardly sit still long enough to hear what Marsh had to say. He seemed less interested than earlier, but promised to hold a tribal council on the question that same evening. The council gave its permission for the American Board to build a mission at their village, but only if other villages would agree to the same proposition. In this way they managed to treat Marsh with some courtesy and still, in effect, refuse his offer.

Since the tribal leaders refused his request, the missionary concentrated on personal contacts among the tribe. For several days he talked to anyone who would listen, hoping to convert them to Christianity. Over breakfast several days later, he again broached the subject to Appenoose. The chief explained his beliefs, and Marsh used the opportunity "to speak of Jesus Christ and the resurrection and [to] explain it by a picture representing $t[h e]$ rising of $t[h e]$ dead at $t$ [he] last day." When he finished, the chief "replied that he thought it was best to enjoy ourselves in this life and not trouble ourselves with gloomy thoughts."

Although he certainly tried, the missionary was unable to change the chief's views, or for that matter, those of any other Indians he met on the tour. His paramount problem was communication with the Indians. If he had been able to understand or speak their language, perhaps the results might have been more to his liking. As it was, he had to depend on interpreters, and this in itself proved a problem. Antoine Le Claire, the U. S. interpreter at Rock Island, was Catholic and refused to aid Protestant missionaries among the Indians. Marsh hired a half-breed, who "could speak the language as well as the Indians themselves," but felt he could not be trusted. He complained about the lack of good interpreters saying, "Although there are many on the Mississippi that can speak a little of the language, still there are not more than three or four who can express moral or religious ideas."

After failing to convince the chief at breakfast, he tried again later that afternoon. This effort too, ended in failure, 
and another canoe loaded with whiskey kegs arrived. Thus the merriment resumed with drunken revelry and savage yelling finally driving Marsh from the village. He retired to a small patch of woods and spent the rest of the day alone. When the whiskey supply diminished and most of the Indians were resting, he returned. Appenoose feared some drunken brave might attack the missionary, so he placed a guard in his lodge.

His stay in the village gave Marsh a chance to observe Indian life firsthand. He attended several feasts and seemed to enjoy Indian cooking. The braves' leisurely habits, however, appalled him. They rarely did any physical labor, and to him this was inexcusable. He described their way of life saying they "spend their time, some in playing cards, others in fixing their ornaments . . . in smoking and lounging upon couches or in going fr[om] lodge to lodge, telling stories or trifling conversation." While the braves enjoyed this idyllic existence, the women "perform all of $\mathrm{t}$ [he] hard labor such as the] men ought." Obviously Indian society was in deplorable condition, and could only be corrected by Christian missionaries and teachers.

Seeing his lack of progress, Marsh left Appenoose's village early August 12. The chief presented him a shoulder of venison, and they parted on good terms. Several traders and Indians accompanied the missionary by horseback to Keokuk's village, near the Iowa River only 12 miles west of the Mississippi. That evening, while halted because of a thunder storm, Marsh asked one of the young braves, "Who made the thunder?" He replied, "Nah-nah-make-on" (the Thunder God). Then Marsh told them the Great Spirit made all things, but they rejected this, calling him a liar.

They reached their destination early August 14, and the Indians provided the usual welcome, food, and lodging for them. After visiting briefly, Marsh canoed down the Mississippi to a small settlement below Yellow Banks (perhaps what later became Oquawka, Illinois). Here he met a Mister Jemison (Jamison) who invited him in. These two men spent the evening discussing Indians, missions, and Marsh's plans. During the conversation Jemison told the missionary "they (the Indians) can't be Christianized until they are moralized. 
Learn them to work and go to work with them and teach them how to farm-that is the way to do them good."

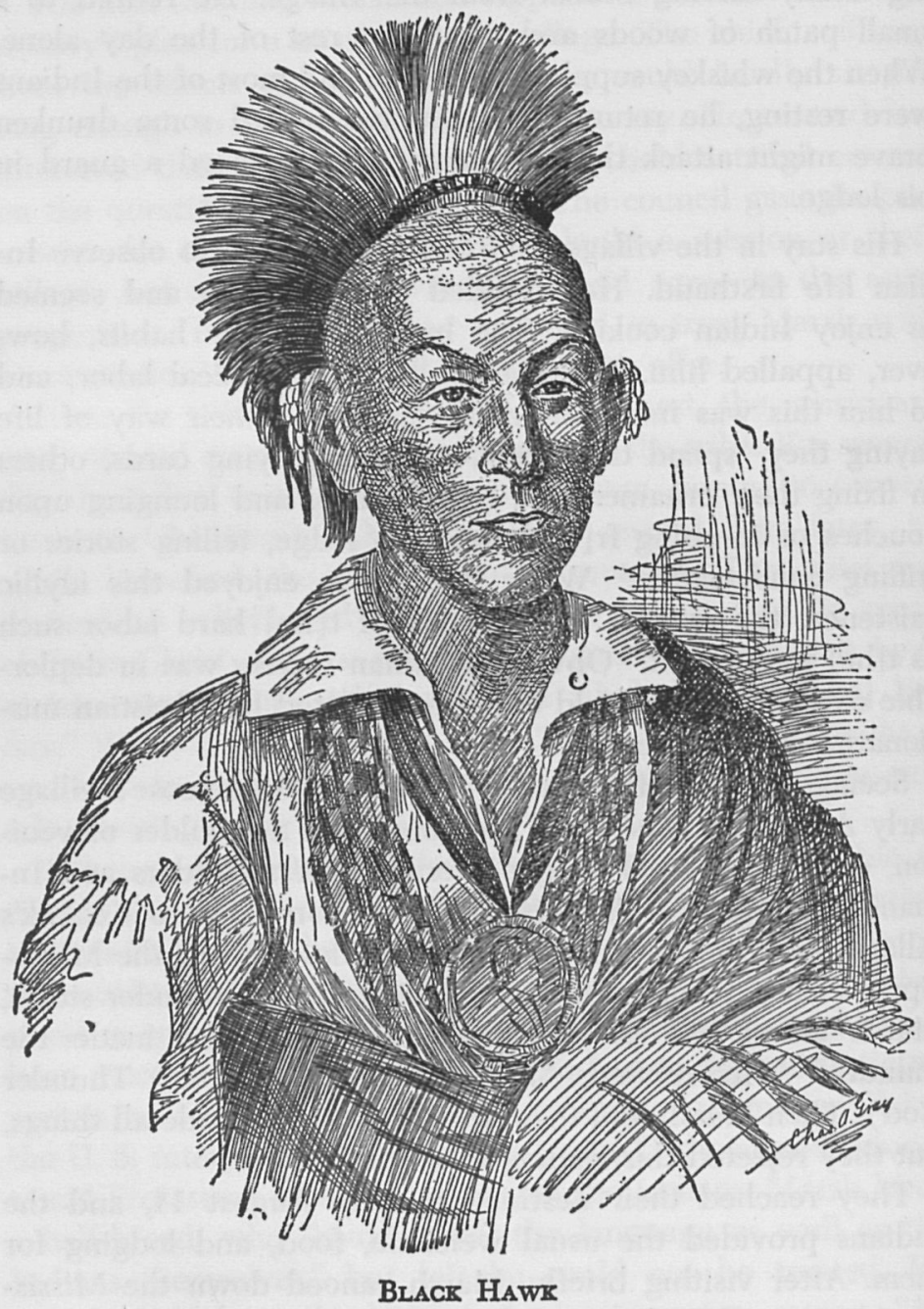

Early the next morning Marsh joined Black Hawk and a party of 40 or 50 Indians with five large canoes. The short trip to Yellow Banks proved rather pleasant, and he was particularly impressed with Black Hawk's son, thinking him very clever. Being with the Indians and yet unable to help 
them spiritually hurt the missionary, and he dejectedly wrote, "As I looked around . . . I thought what excellent and useful men they might make if enlightened by the gospel, but now spend their time and talents to no valuable purpose."

The following day at Yellow Banks, he met Black Hawk for a long personal interview with a Doctor Rupell acting as interpreter. One topic of discussion was the book, The Life of Black Hawk. From his comments to Antoine Le Claire and the trader, George Davenport, the Indian seemed surprised that a book had been written about his life. According to Marsh, he was displeased that the material had been given to Patterson for publication without his knowledge or permission.

Marsh spent the next few days unsuccessfully searching for a good interpreter to accompany him. Finally convinced that the only place to locate a suitable man was Rock Island, he boarded a steamboat headed there and busied himself passing out missionary tracts and literature to the other passengers. The boat reached its destination about noon August 23, and the missionary moved his personal belongings to the Indian agency house there.

After a brief search he found an interpreter, and the next morning they left for the Red Cedar and Iowa River region. Marsh planned to travel in a rough circle, first going west up the Red Cedar and then returning to Keokuk's village. The two men traveled rapidly and soon reached Wah-pel-lo's village about ten miles up the Iowa River from that of Keokuk. Once again the chief was absent with most of the tribe, so Marsh stopped just long enough to ask a few questions. From here they moved up the Red Cedar another ten miles coming to Poweshiek's village which contained about 40 lodges and nearly 400 Indians.

Here the natives invited Marsh and his party to stay for a sacred feast at the chief's lodge. After the ceremony, which lasted three or four hours, Marsh and the chief met briefly. The missionary asked his host what sort of instruction he would like for his young men. "He replied that he should like to have two or three educated for interpreters . . . but he did not want schools for he wished to have his young men warriors and they did not like to be confined in a house." Their 
conversation drifted to farming methods, and eventually, of course, to religion. Marsh explained the Christian beliefs, and illustrated his efforts with a picture drawn on the dirt floor. After some time Poweshiek interrupted and asked the missionary to stop his vivid description of the Judgment "for it made him afraid-afraid that he should dream about it."

Unable to make appreciable headway with the chief, Marsh began talking to some braves nearby. He showed them a sample of Ojibwa writing, and, noting their interest, asked if they wanted to learn writing. They replied that they had no teachers. Their answer to his inquiry about getting teachers for the village was, "they did not want to learn for they wanted to kill Sioux." These Indians were not impressed by either Marsh or Christianity, and refused to change their mode of life or to adopt the white man's ideas or practices. One old man asked the missionary if carrying the "good book" would help them in a contemplated raid on a nearby Sioux encampment.

That evening, the Indians received a large whiskey supply, and Marsh complained "A drunken frolic followed ... and the village was disturbed during the whole of [the night] by the sound of revelry and intoxicated Indians." Several braves stole his horses and apparently rode them most of the night because he described them as "considerably damaged" when they returned the next morning. Continuing his unsuccessful efforts to generate support, Marsh became depressed. He had little hope of establishing a mission among these Indians and characterized their tribe by saying, "The Foxes appear generally more addicted to drinking than the Sacs and consequently [are] more debased."

On August 29, having failed again, the disspirited missionary and his interpreter moved to Keokuk's village. The chief received them politely, but coolly, and showed no interest in learning why they had come. A short time later, while Marsh was absent, he told the interpreter "that he knew what [they] had come for, but he did not want to hear anything about it."

The missionary blamed their curt refusal on the influence of George Davenport, the fur trader, and Antoine Le Claire, the U. S. interpreter. He recalled what John Metoxen, a Stock- 
bridge chief, said about a discussion with Black Hawk regarding missionaries and missions. The Sac chief had told the Stockbridges, "the trader, Mr. D[avenport] told me not to have anything to do with them [missionaries] for they would only make you worse."

That evening several braves opened a keg of whiskey and then took Marsh's horses. When Keokuk made no attempt to retrieve them, the missionary angrily demanded that he find or replace the lost horses. After a heated argument the chief told Marsh he had no business in the village, and that the care of his horses was his own affair. This convinced him there was no chance of getting Keokuk to accept a school or mission for the village, so after recovering his much abused horses, Marsh quickly packed. Before leaving, however, he stopped for another visit with Black Hawk who lived in the village. To his dismay, he found the Indian had gone to Rock Island, and saw only his family.

That afternoon Marsh, his interpreter, and several Indians left the village and headed for the Iowa River. They camped along its banks, and the missionary again tried to interest the braves in Christianity, but still without success. As they crossed the river the next morning, he said it was, "with mingled emotions of pity \& sorrow I crossed $t$ [he] Iowa and set my face towards Rock Island ... Never before this short tour have I witnessed or experienced so fully $t$ [he] meaning of those words 'and they made light of it."

Once across the river, Marsh hailed a canoe of passing Indians who agreed to lead his party to the Mississippi. That night they stayed at a small Fox and Winnebago village where the Prophet, who had encouraged Black Hawk's ill-fated resistance to the whites in 1831-32, lived in comparative obscurity. Marsh had met him at Statesburg in 1833, and stopped to visit for a while before continuing on to Rock Island.

From here he again traveled northward, stopping at several other villages along the way. He described this part of the journey saying, "there are a number of others [villages] which hardly seem worthy of the name scattered [a]round in various places . . . some of which I visited; and others I did not think it worth the while."

The remainder of the trip to Rock Island passed quickly, 
and after several days there, he boarded a steamboat bound for Galena, Illinois. He arrived early Sunday, September 7, and joined the Reverend Arastus Kent, a Methodist missionary there. Marsh felt happy to be among civilized people again, and remarked that it was a "blessing and a pleasure to be in company of an educated, Christian man."

From Galena he traveled on horseback to Mineral Point, in the Wisconsin lead-country. Staying there for the weekend, he left for Fort Winnebago at the Fox-Wisconsin portage. Here poor weather made roads impassable and detained him nearly a week. At the fort, Marsh met Mr. Daniel Whitney, a Green Bay merchant and acquaintaince. These two traveled to Statesburg together, arriving on the evening of September 19. Thus, the tour, which covered over 1300 miles by land and water and lasted three months and eight days, came to an end.

Although tired and happy to be home once again, Marsh had to evaluate his tour for the American Board. He told them he was unable to change the Indians' attitudes toward Christianity and white man's education, and carefully discussed the obstacles to be overcome.

One of these was "opposition from white men," referring to the Indian traders and some frontier settlers. If the Indians became even slightly educated, Marsh claimed, they would be more difficult to cheat and swindle, thus the opposition to any scheme for their education. Another, and more difficult problem was to change the Indians' habits and culture so they might accept schools and perhaps, in time, churches. He mentioned this because "their indolence and roving habits" made it extremely unlikely any mission would be accepted. Constant warfare with the Sioux also kept the tribes in turmoil. For a mission or school to succeed, the Indians would have to give up their annual hunts and settle down as agriculturists, which was highly unlikely.

Sometime later, in a letter to General Joseph M. Street, then new agent to the Sac and Fox tribes, Marsh explained his views, saying:

I know also that at the present as a general thing they are opposed to any alterations or innovations upon former modes of life or customs ... But, Sir their wretchedness, 
their state of deterioration and above all their perishing condition as immortal beings should lead us as philanthropists and as Christians to make most vigorous and unwearied efforts to prevent the tide of intemperance and vice . . . from sweeping them all away.

The missionary had done his best. He spent an entire summer traversing the plains and rivers of eastern Iowa. $\mathrm{He}$ talked with tribal and village leaders in council, with the Indian women as they worked, and with the braves as they lounged or traveled. Finally, he tried to get the cooperation of local fur traders and Indian agents, all to no avail. The Sac and Fox Indians showed no inclination to accept either education or Christianity in 1834. During the following decades "the Indians protested vigorously and successfully" against having their tribal funds spent for education. In 1841 Keokuk restated his opposition by saying, "As to the proposal to build school houses, we have always been opposed to them, and will never consent to have them introduced into our nation." This opposition continued unabated until the 1860's when it finally began to soften.

Thus, Marsh's failure to gain a foothold for Christianity proved only one in a long line of rebuffs for the white man's culture and religion. The Sac and Fox Indians were not ready to try the ways of the white man in 1834. Marsh tried and failed, and others followed, however, without success. 
Copyright of Annals of Iowa is the property of State of Iowa, by \& through the State Historical Society of Iowa and its content may not be copied or emailed to multiple sites or posted to a listserv without the copyright holder's express written permission. However, users may print, download, or email articles for individual use. 